\title{
Challenges to promote the rational use of psychotropic drugs
}

\author{
Desafios para promover o uso racional de \\ drogas psicotrópicas
}

\author{
Desafíos para promover el uso racional de \\ drogas psicotrópicas
}

Diego Zapelini do Nascimento 1
Gabriela Moreno Marques 1

doi: 10.1590/0102-311X00242518
Dear Editors,

Recently, an article entitled Adverse Drug Events Identified in Hospitalized Patients in Brazil by International Classification of Diseases (ICD-10) Code Listings was published in CSP 1 . This study examined the potential of applying ICD-10 codes to a national database of the public health care system (Hospital Information Systems of the Brazilian Unified National Health Syustem - SIH-SUS) to contribute to learning about adverse drug events (ADEs) in hospitalized patients. The study stated that 14 out of 20 most frequent ADEs were identified in codes relating to mental disorders. This result study encourages us to contribute to the debate pertaining the prescription of psychotropic drugs, illustrating the concern upon this type of prescription, which turned into an epidemic in the Brazil and has been a challenge for all regulatory agencies around the world. First, in some countries such as Brazil, the safe and effective use of psychopharmaceuticals needs revision by health professionals and university researchers. Second, prescription of psychoactive drugs should be based on the principles of Integrative and Complementary Practices 2. Third, the electronic health records (EHRs) in psychiatric care should be adopted and improved. Although the EHRs represent a key component of the health care redesign, they do not meet all the needs of the health care providers and rarely benefit patients using psychotropic drugs 3 . Fourth, there is a lack of cohesion within health care providers focusing on patient safety. Joining knowledge and practices of distinct areas that compose the health team at the scientific and technical level is vital for a successful multidisciplinary work 4 . In Brazil, the multidisciplinary work to provide care for patients with mental disorders, chemical dependence, and psychoactive drug use is the responsibility of the Psychosocial Care Centers (known by the Portuguese acronym CAPS) linked to the public health system. However, because of government funding shortage, the rational use of psychoactive drugs does not have adequate monitoring and control, since access to them may occur differently from that advocated by the policies 5 . In this sense, all regulatory agencies will have major challenges in identifying and developing practices to stimulate the rational use of psychotropic drugs.
1 Universidade do Sul de Santa Catarina, Tubarão, Brasil.

\section{Correspondence}

D. Z. Nacimento

Universidade do Sul de Santa Catarina.

Av. José Acácio Moreira 787, Tubarão, SC 88704-900, Brasil.

diegozapnasc@gmail.com 


\section{Contributors}

D. Z. Nascimento wrote the first version of the manuscript and have approved the final letter. G. M. Marques reviewed the letter, contributed to and approved the final version.

\section{Additional informations}

ORCID: Diego Zapelini do Nascimento (00000002-7323-185X); Gabriela Moreno Marques (0000-0001-9296-7574).

\section{References}

1. Martins AC, Giordani F, Guaraldo L, Tognoni G, Rozenfeld S. Adverse drug events identified in hospitalized patients in Brazil by International Classification of Diseases (ICD-10) code listings. Cad Saúde Pública 2018; 34:e00222417.

2. Gardner DM. Competent psychopharmacology. Can J Psychiatry 2014; 59:406-11.

3. Busch AB, Bates DW, Rauch SL. Improving adoption of EHRs in psychiatric care. N Engl J Med 2018; 378:1665-7.

4. Leotsakos A, Ardolino A, Cheung R, Zheng H, Barraclough B, Walton M. Educating future leaders in patient safety. J Multidiscip Healthc 2014; 7:381-8.

5. Bezerra IC, Morais JB, Paula ML, Silva TMR, Jorge MSB. Uso de psicofármacos na atenção psicossocial: uma análise à luz da gestão do cuidado. Saúde Debate 2016; 40:148-61. 